\title{
APPLYING PARETO FRONTIER TO DETERMINE CONTROL STRATEGY OF TECHNICAL OBJECTS OPERATION PROCESS
}

\author{
ZASTOSOWANIE FRONTU PARETO DO \\ WYZNACZANIA STRATEGII STEROWANIA \\ PROCESEM EKSPLOATACJI OBIEKTÓW \\ TECHNICZNYCH
}

\author{
Klaudiusz Migawa ${ }^{1)}$, Leszek Knopik ${ }^{1)}$, Andrzej Neubauer ${ }^{2)}$, Agnieszka \\ Soltysiak $^{1)}$ \\ ${ }^{1)}$ Uniwersytet Technologiczno-Przyrodniczy w Bydgoszczy \\ ${ }^{2)}$ Uniwersytet Mikołaja Kopernika w Toruniu
}

\begin{abstract}
The paper deals with the multi-criteria model of technical objects operation process control in which the choice of control strategy is made with the use of nondeterministic methods. The decisive model was created with the use of decisive theories of semi-Markov processes. The choice of the optimum (quasioptimum) solution is made with the use of simulated annealing algorithm. As a result of numeric calculations for used criteria functions (availability, risk), a set of quasi-optimum solutions in the form of Pareto frontier is obtained.
\end{abstract}

Keywords: control strategy, Pareto front, availability, risk

Streszczenie: $W$ artykule przedstawiono wielokryterialny model sterowania procesem eksploatacji obiektów technicznych, w którym wybór strategii sterowania realizowany jest $z$ zastosowaniem metod niedeterministycznych. Model decyzyjny zostat opracowany z wykorzystaniem teorii decyzyjnych procesów semi-Markowa. Wybór rozwiazania optymalnego (quasi-optymalnego) realizowany jest za pomoca algorytmu symulowanego wyżarzania. $W$ wyniku realizacji obliczeń numerycznych, dla zastosowanych funkcji kryterialnych (gotowość, ryzyko), uzyskuje się zbiór rozwiazań quasi-optymalnych w postaci frontu Pareto.

Stowa kluczowe: strategia sterowania, front Pareto, gotowość, ryzyko 
Applying Pareto frontier to determine control strategy of technical objects... Zastosowanie frontu Pareto do wyznaczania strategii sterowania procesem...

\section{APPLYING PARETO FRONTIER TO DETERMINE CONTROL STRATEGY OF TECHNICAL OBJECTS OPERATION PROCESS}

\section{Introduction}

In complex technical objects operation systems, the selection of rational control decisions from possible decisive variants is should be carried out with the implementation of appropriate methods and mathematical tools rather than "intuitively" based solely on the knowledge and experience of the deciders of the systems. Introducing appropriate mathematical methods of operation process control facilitates selecting rational control decisions in a way which provides correct and effective carrying out of tasks assigned to the system. Evaluation criteria may include: availability of the system to carry out assigned tasks; reliability of the utilized technical objects; efficiency and effectiveness of the carried out processes; safety of technical system, human and environment; risk of undesired events; costs and profits generated by the technical object or operation process in the time interval or occurring per time unit, production unit, amount of work performed or energy used, as well as in conversion to hour or kilometer course. One of the methods for an assessment of the system ability to perform its task properly is to establish the availability and the risk connected with the technical object functioning.

Due to the complexity of the modeled processes and technical systems, there is a need for use of appropriate methods and tools ensuring effective realization of research and analysis of results obtained. Depending on the kind of analyzed research problems, appropriate methods of delineating optimal and quasi-optimal solutions were implemented, e.g.: $[2,5,6,7,8,9$, 13]. Simulated annealing algorithm belongs to the group of nondeterministic methods of defining optimal solution. Available reference sources include numerous works on theoretical description as well as examples of practical implementation of simulated annealing algorithm in searching for optimal solution, e.g.: $[1,4,10,11,12,14]$. Using these methods made it possible to arrive at solutions in complicated issues of multi criteria optimization in a simple and fast way. The most important methods include: multiobjective optimization simulated annealing MOSA with use Paretodomination based acceptance criterion as well as archived multiobjective optimization simulated annealing AMOSA.

The paper presents a description of the method of determining the optimal (quasioptimal) strategy of technical objects operation process with the implementation of decisive semi-Markov processes as well as multi criteria simulated annealing algorithm in which the result constitutes the set of optimal solutions according to Pareto (the so-called Pareto frontier). The method discussed in the paper allows for determining the strategy of technical objects control process from the point of view of the values of selected criteria functions (availabilitty, risk). 


\section{Event model of operation and maintenance process of transport means}

The model of the operation and maintenance process was created on the basis of the analysis of the space of operation and maintenance states and events connected with technical objects (transport means) operating in the analyzed authentic transport system. Due to the criterion of risk in the observed system functioning, based on the identification of the carried out multi-state operation and maintenance process of technical object, crucial states of the process were identified as well as possible passages between the selected states. On such basis a graph was created showing changes of the states of operation and maintenance process, presented in figure 1 .

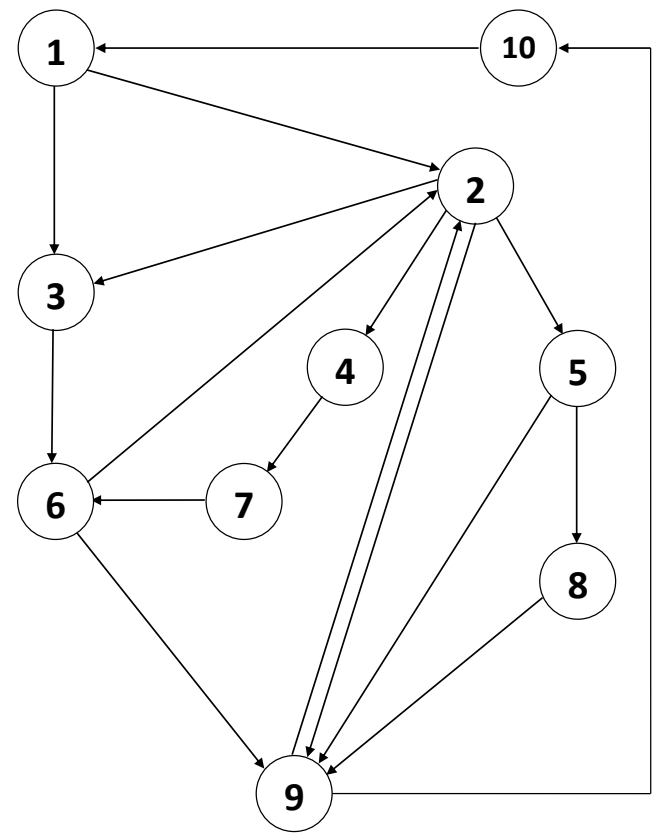

Fig. 1 Directed graph representing the transport means operation and maintenance process: $\mathbf{1}$-stopover at depot parking space, $\mathbf{2}$-carrying out of transport task, $\mathbf{3}$ - intervention of technological emergency unit after damage (unwelcome event), $\mathbf{4}$-accident, collision (unwelcome event), 5 - preventive diagnosis, $\mathbf{6}$ - regeneration after unwelcome event, 7 -intervention and rescue action, 8 - preventive regeneration, 9 - supply, 10 - servicing (operation day, periodical, seasonal)

\section{Decisive model of determining control strategy}

Due to the random nature of the factors influencing the running of the technical objects (transport means) operation process introduced in a complex system, most often in the process mathematical modelling of the operation process, stochastic processes are used. 
Applying Pareto frontier to determine control strategy of technical objects... Zastosowanie frontu Pareto do wyznaczania strategii sterowania procesem...

Random process includes a wide implementation of Markov and semi-Markov process for modelling the operation process for technical objects, whereas in the case of the issues involving control of operation processes, decision-making Markov and semi-Markov processes are used.

Assuming that the analyzed model of technical object operation process is a random process $\{X(t): t \geq 0\}$ of finite number of process states $i \in S=\{1,2, \ldots, m\}$, then

$$
D_{i}=\left\{d_{i}^{(1)}\left(t_{n}\right), d_{i}^{(2)}\left(t_{n}\right), \ldots, d_{i}^{(k)}\left(t_{n}\right)\right\}
$$

means a set of all possible control decisions which can be implemented in $i$-state of the process at the moment of $t_{n}$, where $d_{i}^{(k)}\left(t_{n}\right)$ means $k$-control decision made in $i$-state of the process, at the moment of $t_{n}$.

In the case of optimization task involving the choice of optimal strategy of technical object operation process control from among the acceptable strategies, then as the strategy we understand the $\delta$ sequence, where the words are the vectors, comprising of the decision $d_{i}^{(k)}\left(t_{n}\right)$ made in the following moments of the $t_{n}$ changes of the state of the process $X(t)$

$$
\left.\delta=\left\{d_{1}^{(k)}\left(t_{n}\right), d_{2}^{(k)}\left(t_{n}\right), \ldots, d_{m}^{(k)}\left(t_{n}\right)\right]: \quad n=0,1,2, \ldots\right\} .
$$

In order to determine the optimal control strategy (decision sequence) it is possible to implement decision-making semi-Markov processes. The decisive semi-Markov process is a stochastic process $\{X(t): t \geq 0\}$, the implementation of which depends on the decisions made at the beginning of the process $t_{0}$ and at the moments of changing the process $t_{1}, t_{2}, \ldots, t_{n}, \ldots$. At work it is assumed that the analyzed semiMarkov process possess a limited number of states $i=1,2, \ldots, m$. In case of implementation of the decisive semi-Markov processes making the decision at the moment of $t_{n}, k$-controlling decision in $i$-state of the process means a choice of $i$ verse of the core of the matrix from the following set

$$
\left\{Q_{i j}^{(k)}(t): t \geq 0, \quad d_{i}^{(k)}\left(t_{n}\right) \in D_{i}, \quad i, j \in S\right\},
$$

where

$$
Q_{i j}^{(k)}(t)=p_{i j}^{(k)} \cdot F_{i j}^{(k)}(t) .
$$

The choice of the $i$-verse of the core of the process specifies the probabilistic mechanism of evolution of the process in the period of time $\left.<t_{n}, t_{n+1}\right)$.

This means that for the semi-Markov process, in case of the change of the state of the process from one into $i$-one (entry to the $i$-state of the process) at the moment $t_{n}$, the decision is made $d_{i}^{(k)}\left(t_{n}\right) \in D_{i}$ and according to the schedule $\left(p_{i j}^{(k)}: j \in S\right) j$ state of the process is generated, which is entered at the moment of $t_{n+1}$. 
At the same time, in accordance with the schedule specified by the distributor $F_{i j}^{(k)}(t)$, the length of the period of time is generated $\left\langle t_{n}, t_{n+1}\right)$ to leave the $i$-state of the process, when the next state is the $j$-state.

The choice of appropriate control strategy $\delta$ called the optimal strategy $\delta$, concerns the situation, when the function (functions) representing the selection criterion of the optimal strategy takes an extrene value (minumum or maximum)

$$
f_{C}\left(\delta^{*}\right)=\min _{\delta}\left[f_{C}(\delta)\right] \text { or } f_{C}\left(\delta^{*}\right)=\max _{\delta}\left[f_{C}(\delta)\right] .
$$

In the paper, the criteria functions are the availability of individual technical object $A^{O T}(\delta)$ and the unit risk of unwelcome event $r^{O T}(\delta)[\mathrm{PLN} / \mathrm{h}]$ :

$$
\begin{gathered}
f_{C_{1}}(\delta)=A^{O T}(\delta)=\sum_{i \in S_{A}} p_{i}^{*}(\delta)=\frac{\sum_{i \in S_{A}} \pi_{i} \cdot \Theta_{i}(\delta)}{\sum_{i \in S} \pi_{i} \cdot \Theta_{i}(\delta)}, \\
f_{C_{2}}(\delta)=r^{O T}(\delta)=\sum_{i \in S_{U}} c_{i}(\delta) \cdot p_{i}^{*}(\delta)=\frac{\sum_{i \in S_{U}} c_{i}(\delta) \cdot \pi_{i} \cdot \Theta_{i}(\delta)}{\sum_{i} \pi_{i} \cdot \Theta_{i}(\delta)},
\end{gathered}
$$

where:

$S_{A} \subset S$ - set of availability states of modeled operation and maintenance process,

$S_{U} \subset S$ - set of unwelcome states of modeled operation and maintenance process,

$c_{i}(\delta) \quad-$ unit incomes generated in the states of process $X(t)$,

$p_{i}^{*}(\delta) \quad$ - limit probabilities of remaining in states of the analyzed process $X(t)$ were determined based on limit theorem for semi-Markov processes [3]

$$
p_{i}^{*}(\delta)=\frac{\pi_{i} \cdot \Theta_{i}(\delta)}{\sum_{i \in S} \pi_{i} \cdot \Theta_{i}(\delta)},
$$

where:

$\Theta_{i}(\delta) \quad-$ average values of unconditional duration of the states of process,

$\pi_{i} \quad-$ probabilities of stationary distribution of the complex Markov chain fulfilling the system of linear equations

$$
\sum_{i \in S} \pi_{i} \cdot p_{i j}=\pi_{j}, \quad j \in S, \quad \sum_{i \in S} \pi_{i}=1,
$$

$p_{i j}$ - conditional probability of passing from state $i$ to state $j$ :

$$
\begin{gathered}
p_{i j}=\lim _{t \rightarrow \infty} p_{i j}(t), \\
p_{i j}(t)=P\{X(t)=j \mid X(0)=i\} .
\end{gathered}
$$


Applying Pareto frontier to determine control strategy of technical objects... Zastosowanie frontu Pareto do wyznaczania strategii sterowania procesem...

The choice of the optimal strategy $\delta^{*}$ is made on the basis of the following criterions:

$$
\begin{aligned}
& A^{O T}\left(\delta^{*}\right)=\max _{\delta}\left[A^{O T}(\delta)\right], \\
& r^{O T}\left(\delta^{*}\right)=\min _{\delta}\left[r^{O T}(\delta)\right] .
\end{aligned}
$$

The simulated annealing algorithm constitutes the convenient tool for selection the optimal strategy $\delta^{*}$ of controlling the operation and maintenance process for technical objects on the base of developed semi-Markov model of the process. In case of the implementation of the simulated annealing algorithm to determine the optimal strategy of controlling the operation and maintenance process for technical objects, the following guidelines should be considered:

- the examined stochastic process is the $m$-state decisive semi-Markov process,

- in each state it is possible to implement one of the two decision $D=\{0,1\}$,

- if the decisions are marked as 0 and 1 then the number of control strategies to be implemented for the $m$-state model of the operation and maintenance process of the means of transport amounts to $2^{m}$,

- the set of control strategies is the set of functions $\delta: S \rightarrow D$.

On the basis of the following guidelines each possible control strategy can be presented as $m$-positioning sequence consisting of 0 and 1 . Therefore, an exemplary control strategy for the model of the operation and maintenance process consisting of $m=10$ states can be determined in the following way: $\delta=[1,1,0,1,1,0,1,0,0,1]$. For $10^{\text {th }}$ state semi-Markov model of the means of transport operation and maintenance process presented in figure 1 as well as data obtained from tests of the existing operation and maintenance system, calculations were made with the help of developed computer software, implemented multicriteria simulated annealing algorithm.

\section{Delineating rational control strategy}

The presented example was prepared on the basis of operational data obtained from tests of the existing means of transport operation system (municipal transport buses). In the tested system 182 municipal buses are in use, while the service and repair processes are carried out at technical infrastructure posts as well as technical emergency units. Operation process control is possible as a result of correct decision making at decisive states of the process (table 1).

For the analyzed model of the process of the functioning means of transport, basing on the functioning data, values were estimated for the elements of matrix $P$ of passage probabilities, possible decisions made in the decisive states of the process (table 1) as well as unconditional times and unit profit generated in the states of process $X(t)$ were determined (table 2 ). 
In the model, the following states of availability were distinguished: $\mathbf{1}$ - stopover at depot parking space, $\mathbf{2}$ - carrying out of transport task; as well as the following unwelcome states were distinguished: $\mathbf{3}$-intervention of technological emergency unit after damage, $\mathbf{4}$ - accident, collision, $\mathbf{6}$ - regeneration after unwelcome event, 7 - intervention and rescue action.

$P=\left|\begin{array}{cccccccccc}0 & 0.9609 & 0.0391 & 0 & 0 & 0 & 0 & 0 & 0 & 0 \\ 0 & 0 & 0.2321 & 0.0030 & 0.4988 & 0 & 0 & 0 & 0.2661 & 0 \\ 0 & 0 & 0 & 0 & 0 & 1 & 0 & 0 & 0 & 0 \\ 0 & 0 & 0 & 0 & 0 & 0 & 1 & 0 & 0 & 0 \\ 0 & 0 & 0 & 0 & 0 & 0 & 0 & 0.0799 & 0.9201 & 0 \\ 0 & 0.4702 & 0 & 0 & 0 & 0 & 0 & 0 & 0.5298 & 0 \\ 0 & 0 & 0 & 0 & 0 & 1 & 0 & 0 & 0 & 0 \\ 0 & 0 & 0 & 0 & 0 & 0 & 0 & 0 & 1 & 0 \\ 0 & 0.2242 & 0 & 0 & 0 & 0 & 0 & 0 & 0 & 0.7758 \\ 1 & 0 & 0 & 0 & 0 & 0 & 0 & 0 & 0 & 0\end{array}\right|$

Tab. 1 Decisions in the states of analyzed process

\begin{tabular}{|c|c|c|}
\hline $\begin{array}{c}\text { Process } \\
\text { state }\end{array}$ & Decision, $0 ”-d_{i}^{(0)}$ & Decision , $1 ”-d_{i}^{(1)}$ \\
\hline 2 & $\begin{array}{l}\text { Route marked with code } \mathrm{L} \\
\text { ("light" conditions of carrying } \\
\text { out transport task) }\end{array}$ & $\begin{array}{l}\text { Route marked with code } \mathrm{H} \\
\text { ("hard" conditions of carrying } \\
\text { out transport task) }\end{array}$ \\
\hline 3 & $\begin{array}{l}\text { Intervention by TE unit type B } \\
\text { (basic range) }\end{array}$ & $\begin{array}{l}\text { Intervention by TE unit type } \mathrm{E} \\
\text { (expended range) }\end{array}$ \\
\hline 5 & $\begin{array}{l}\text { Preventive diagnostics type B } \\
\text { (basic range) }\end{array}$ & $\begin{array}{l}\text { Preventive diagnostics type } \mathrm{E} \\
\text { (extended range) }\end{array}$ \\
\hline 6 & $\begin{array}{l}\text { Regeneration after unwelcome } \\
\text { event type B (basic range) }\end{array}$ & $\begin{array}{l}\text { Regeneration after unwelcome } \\
\text { event type E (extended range) }\end{array}$ \\
\hline 7 & $\begin{array}{l}\text { Intervention and rescue mission } \\
\text { type } \mathrm{R} \text { (regular) }\end{array}$ & $\begin{array}{l}\text { Intervention and rescue mission } \\
\text { type I (intensive) }\end{array}$ \\
\hline 8 & $\begin{array}{l}\text { Preventive regeneration type B } \\
\text { (basic range) }\end{array}$ & $\begin{array}{l}\text { Preventive regeneration type } \mathrm{E} \\
\text { (extended range) }\end{array}$ \\
\hline 9 & Servicing type R (regular) & Servicing type I (intensive) \\
\hline
\end{tabular}


Applying Pareto frontier to determine control strategy of technical objects... Zastosowanie frontu Pareto do wyznaczania strategii sterowania procesem...

Tab. 2 Average unconditional duration times $\bar{\Theta}_{i}$ as well as unit incomes $c_{i}$ generated depending on the decision made in states of process $X(t)$

\begin{tabular}{|c|c|c|c|c|}
\hline $\begin{array}{c}\text { Process } \\
\text { state }\end{array}$ & $\bar{\Theta}_{i}^{(0)}[\mathrm{h}]$ & $\bar{\Theta}_{i}^{(1)}[\mathrm{h}]$ & $c_{i}^{(0)}[\mathrm{PLN} / \mathrm{h}]$ & $c_{i}^{(1)}[\mathrm{PLN} / \mathrm{h}]$ \\
\hline $\mathbf{1}$ & 5.659 & 5.659 & -6.77 & -6.77 \\
\hline $\mathbf{2}$ & 8.852 & 7.967 & 28.44 & 33.56 \\
\hline $\mathbf{3}$ & 0.586 & 0.714 & -127.09 & -79.08 \\
\hline $\mathbf{4}$ & 0.373 & 0.373 & -242.80 & -242.80 \\
\hline $\mathbf{5}$ & 0.814 & 0.577 & -54.98 & -83.79 \\
\hline $\mathbf{6}$ & 2.888 & 2.303 & -98.97 & -121.70 \\
\hline $\mathbf{7}$ & 2.212 & 1.739 & -403.63 & -538.18 \\
\hline $\mathbf{8}$ & 2.940 & 2.150 & -86.89 & -112.98 \\
\hline $\mathbf{9}$ & 0.452 & 0.452 & -23.09 & -23.09 \\
\hline $\mathbf{1 0}$ & 0.682 & 0.454 & -164.72 & -204.72 \\
\hline
\end{tabular}

Then, calculations were performed with the help of the developed computer program, implementing the simulated annealing algorithm, written at: $R$ Development Core Team (2017). $R$ : A language and environment for statistical computing. $R$ Foundation for Statistical Computing, Vienna, Austria. ISBN 3-900051-07-0. On the basis of the calculations performed, for the criteria adopted, optimal (quasi-optimal) control strategies were determined for the operation process carried out at the tested transport system. Calculation results were presented in figures 2 and 3 as well as table 3 .

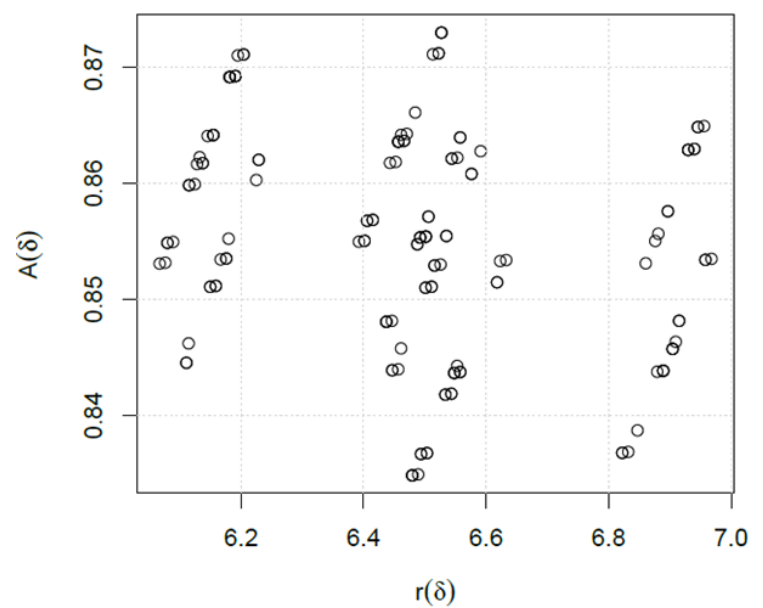

Fig. 2 Results obtained from individual iteration implementing the simulated annealing algorithm 


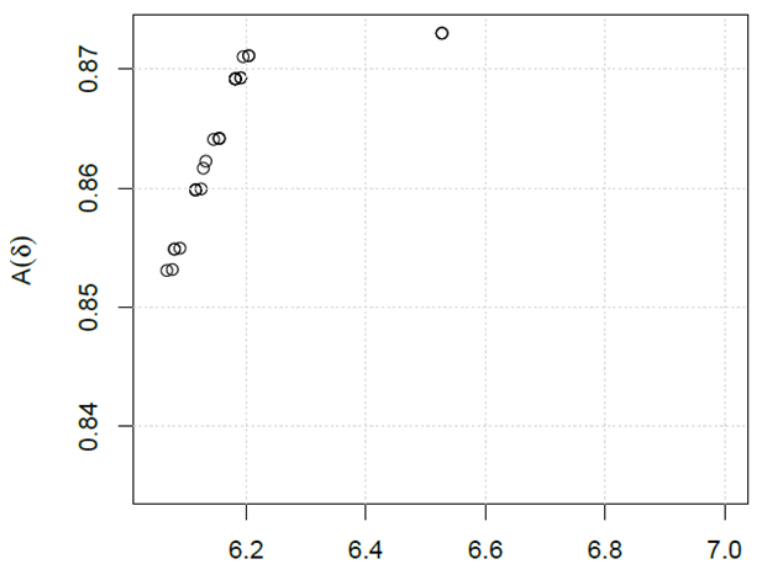

$\mathrm{r}(\delta)$

Fig. 3 Determined Pareto frontier for optimal solutions implementing the simulated annealing algorithm

Tab. 3 Optimal control strategies $\delta^{*}$ as well as value of criteria functions determined on the basis of simulated annealing algorithm

\begin{tabular}{|c|c|c|}
\hline Strategy $\delta^{*}$ & $A\left(\delta^{*}\right)$ & $r\left(\delta^{*}\right)[\mathrm{PLN} / \mathrm{h}]$ \\
\hline$[0,0,1,1,0,1,0,0,0,0]$ & 0.8531 & 6.0673 \\
\hline$[1,0,1,0,0,1,1,0,1,0]$ & 0.8532 & 6.0764 \\
\hline$[1,0,1,1,0,1,0,1,1,0]$ & 0.8549 & 6.0800 \\
\hline$[0,0,1,1,0,1,1,1,1,0]$ & 0.8550 & 6.0892 \\
\hline$[1,0,1,1,1,1,0,0,1,0]$ & 0.8599 & 6.1154 \\
\hline$[1,0,1,0,1,1,1,0,1,0]$ & 0.8599 & 6.1246 \\
\hline$[0,0,1,0,1,1,0,1,1,0]$ & 0.8617 & 6.1283 \\
\hline$[0,0,1,1,0,1,0,0,1,1]$ & 0.8623 & 6.1325 \\
\hline$[0,0,1,1,0,1,0,1,0,1]$ & 0.8641 & 6.1455 \\
\hline$[0,0,1,0,0,1,1,1,1,1]$ & 0.8642 & 6.1548 \\
\hline$[0,0,1,0,1,1,0,0,0,1]$ & 0.8692 & 6.1817 \\
\hline$[0,0,1,1,1,1,1,0,1,1]$ & 0.8693 & 6.1910 \\
\hline$[0,0,1,0,1,1,0,1,1,1]$ & 0.8710 & 6.1949 \\
\hline$[0,0,1,1,1,1,1,1,0,1]$ & 0.8711 & 6.2043 \\
\hline
\end{tabular}

\section{Conclusions}

On the basis of the results of operation tests at the existing system of means of transport operation, input data were determined for the developed simulated annealing algorithm and calculations were performed. As a result, the values of criteria functions as well as a corresponding set of control strategies constituting a set of optimal solutions according to Pareto were determined. 
Applying Pareto frontier to determine control strategy of technical objects... Zastosowanie frontu Pareto do wyznaczania strategii sterowania procesem...

Next, on the basis of the results obtained, a selection of a single solution from the determined set of optimal solutions located on the so-called Pareto frontier may be made. Such selection is usually made by the decider (a group of deciders) on the basis of additional circumstances connected to particular decisive situation as well as current conditions in which the operation system functions.

\section{References}

[1] Czyżak P., Jaszkiewicz A.: Pareto simulated annealing - A metaheuristic technique for multiple-objective combinatorial optimization. J. Multi-Criteria Decision Anal., vol. 7, 1998, 34-47.

[2] Grabski F.: Analiza ryzyka w decyzyjnych semi-markowskich modelach procesu eksploatacji. XXXVIII Zimowa Szkoła Niezawodności, Szczyrk, 2010, 43-52.

[3] Grabski F.: Semi-Markov processes: Applications in system reliability and maintenance. Elsevier, Amsterdam, 2014.

[4] Hapke M., Jaszkiewicz A., Słowiński R.: Pareto simulated annealing for fuzzy multi-objective combinatorial optimization. J. Heuristics, vol. 6, no. 3, 2000, 329-345.

[5] Knopik L., Migawa K., Wdzięczny A.: Profit optimalization in operation systems. Polish Maritime Research, vol. 23, no. 1(89), 2016, 93-98.

[6] Kulkarni V. G.: Modeling and analysis of stochastic systems. Chapman \& Hall, New York, 1995.

[7] Lee K. W.: Stochastic models for random-request availability. IEEE Trans. Reliability 49, 2000, 80-84.

[8] Migawa K., Knopik L., Sołtysiak A., Kolber P.: The method of risk assessment in transport system. Engineering Mechanics, Institute of Thermomechanics Academy of Sciences of the Czech Republic, 2017, 658-661.

[9] Migawa K., Knopik L., Wawrzyniak S.: Application of genetic algorithm to control the availability of technical systems. Engineering Mechanics, Institute of Thermomechanics Academy of Sciences of the Czech Republic, 2016, 386-389.

[10] Nam D. K., Park C.: Multiobjective simulated annealing: A comparative study to evolutionary algorithms," Int. J. Fuzzy Syst., vol. 2, no. 2, 2000, 87-97.

[11] Suman B., Kumar P.: A survey of simulated annealing as a tool for single and multiobjective optimization. Journal of the Operational Research Society, vol. 57, 2006, 1143-1160.

[12] Suppapitnarm A., Seffen K. A., Parks G. T., Clarkson P.: A simulated annealing algorithm for multiobjective optimization," Eng. Opt., vol. 33, 2000, 59-85. 
[13] Szubartowski M., Migawa K., Neubauer A., Knopik L.: Method of determining optimal control strategy. 58 ${ }^{\text {th }}$ International Conference of Machine Design Departments - ICMD 2017, Prague, Czech Republic, 2017, 380-385.

[14] Ulungu E. L., Teghaem J., Fortemps P., Tuyttens D.: MOSA method: A tool for solving multiobjective combinatorial decision problems," J. Multi-Criteri Decision Anal., vol. 8, 1999, 221-236.

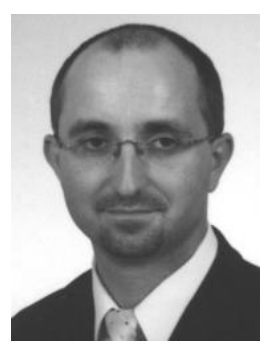

Assoc. Prof. Klaudiusz Migawa, Ph.D. Eng., member of the Faculty of Mechanical Engineering of the UTP University of Science and Technology in Bydgoszcz. In his academic studies, he is preoccupied with the problems of evaluation and control of the level of efficiency, reliability, availability as well as safety of the complex systems of technical objects operation. He is the author of scientific papers in the field of modeling of systems and operation processes of means of transport with the implementation of stochastic processes (Share 25\%).

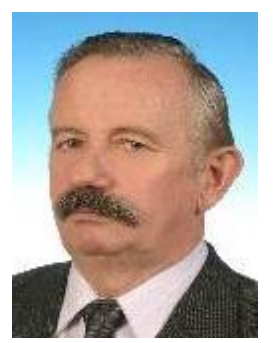

Assoc. Prof. Leszek Knopik, Ph.D., member of the Faculty of Management of the UTP University of Science and Technology in Bydgoszcz. In his academic studies, he deals with the problems of creating mathematical models of complex operation processes, the tasks of theory and practice of reliability. He is the author of academic papers in the area of modeling of systems and processes of technical objects operation with the use of research on operational methods, probability theory as well as Markov and semi-Markov processes (Share 25\%).

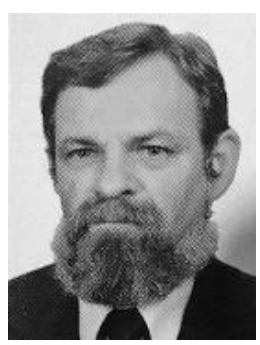

Andrzej Neubauer, D.Sc., member of the Faculty of Economic Sciences and Management of the Nicolas Copernicus University in Toruń. His academic studies include the problems connected to the modeling and simulation of operation processes and process control on the basis of Markov and semi-Markov processes. Moreover, he is interested in the implementation of genetic and evolutionary as well as simulated annealing algorithms in simulation optimization of single and multi-criteria operation processes (Share 25\%).

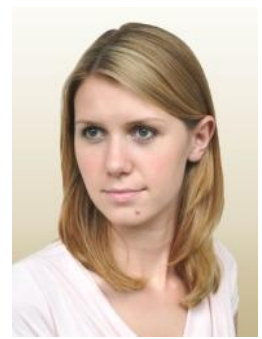

Agnieszka Soltysiak, M.Sc. Eng., member of the Faculty of Mechanical Engineering of the UTP University of Science and Technology in Bydgoszcz. She is a doctoral student at the Faculty of Mechanical Engineering of the UTP in Bydgoszcz in the class of Machine Construction and Operation. In her academic studies, she is preoccupied with the problems of the modeling of technical objects operation as well as control of the safety level of complex technical objects (Share 25\%). 
Applying Pareto frontier to determine control strategy of technical objects...

Zastosowanie frontu Pareto do wyznaczania strategii sterowania procesem...

\section{ZASTOSOWANIE FRONTU PARETO DO WYZNACZANIA STRATEGII STEROWANIA PROCESEM EKSPLOATACJI OBIEKTÓW TECHNICZNYCH}

\section{Wstęp}

W złożonych systemach eksploatacji obiektów technicznych wybór racjonalnych decyzji sterujących, spośród możliwych wariantów decyzyjnych, powinien być realizowany z zastosowaniem odpowiednich metod i narzędzi matematycznych, a nie w sposób „intuicyjny”, oparty wyłącznie na wiedzy i doświadczeniu decydentów systemu. Zastosowanie odpowiednich metod matematycznych do sterowania procesem eksploatacji ułatwia wybór racjonalnych decyzji sterujących, w sposób zapewniający prawidłową i efektywną realizację zadań przydzielonych systemowi. Kryteriami oceny mogą być np.: gotowość systemu do realizacji przydzielonych zadań; niezawodność eksploatowanych obiektów technicznych; wydajność i skuteczność realizowanych procesów; bezpieczeństwo systemu technicznego, człowieka i otoczenia; ryzyko wystąpienia zdarzeń niepożądanych; koszty lub dochody generowane przez obiekt techniczny lub system eksploatacji w przedziale czasu lub przypadające na jednostkę czasu, jednostkę produkcji, ilość wykonanej pracy lub zużytej energii, a także $w$ przeliczeniu na przebieg godzinowy lub kilometrowy. Jednym ze sposobów oceny możliwości prawidłowej realizacji przydzielonego zadania jest wyznaczenie gotowości i ryzyka funkcjonowania obiektów technicznych.

Ze względu na znaczną złożoność modelowanych procesów i systemów technicznych zachodzi potrzeba stosowania odpowiednich metod i narzędzi zapewniających efektywną realizację badań oraz analizę otrzymanych wyników. $\mathrm{W}$ zależności od rodzaju rozpatrywanych problemów badawczych stosowane są odpowiednie metody wyznaczania rozwiązań optymalnych lub quasi-optymalnych, np.: $[2,5,6,7,8,9,13]$. Algorytm symulowanego wyżarzania należy do grupy metod niedeterministycznych wyznaczania rozwiązania optymalnego. W literaturze przedmiotu można znaleźć wiele opracowań dotyczących zarówno teoretycznego opisu, jak i przykłady praktycznych zastosowań algorytmu symulowanego wyżarzania do poszukiwania rozwiązania optymalnego, np.: $[1,4$, $10,11,12,14]$. Zastosowanie tych metod umożliwiło w sposób prosty i szybki uzyskanie rozwiązań $\mathrm{w}$ skomplikowanych zagadnieniach optymalizacji wielokryterialnej. Do najważniejszych metod optymalizacji wielokryterialnej należą: wielokryterialny algorytm symulowanego wyżarzania MOSA z zastosowaniem kryterium akceptacji opartej na dominacji Pareto oraz archiwizowany algorytm symulowanego wyżarzania AMOSA.

$\mathrm{W}$ artykule przedstawiono opis metody wyznaczania optymalnej (quasioptymalnej) strategii sterowania procesem eksploatacji obiektów technicznych z zastosowaniem decyzyjnych procesów semi-Markowa oraz wielokryterialnego algorytmu symulowanego wyżarzania, w której wynik stanowi zbiór rozwiązań optymalnych w sensie Pareto (tzw. front Pareto). 
Przedstawiona $\mathrm{w}$ pracy metoda umożliwia wyznaczenie strategii sterowania procesem eksploatacji obiektów technicznych $\mathrm{z}$ punktu widzenia wartości wybranych funkcji kryterialnych (gotowość, ryzyko).

\section{Zdarzeniowy model procesu eksploatacji środków transportu}

Model procesu eksploatacji został zbudowany na podstawie analizy przestrzeni stanów oraz zdarzeń eksploatacyjnych dotyczących obiektów technicznych (środków transportu) eksploatowanych $\mathrm{w}$ analizowanym rzeczywistym systemie transportowym. Ze względu na kryterium ryzyka działania rozpatrywanego systemu, na podstawie identyfikacji realizowanego wielostanowego procesu eksploatacji obiektów technicznych, wyznaczono istotne stany eksploatacyjne tego procesu oraz możliwe przejścia między wyróżnionymi stanami. Na tej podstawie zbudowano graf zmian stanów procesu eksploatacji, przedstawiony na rysunku 1 .

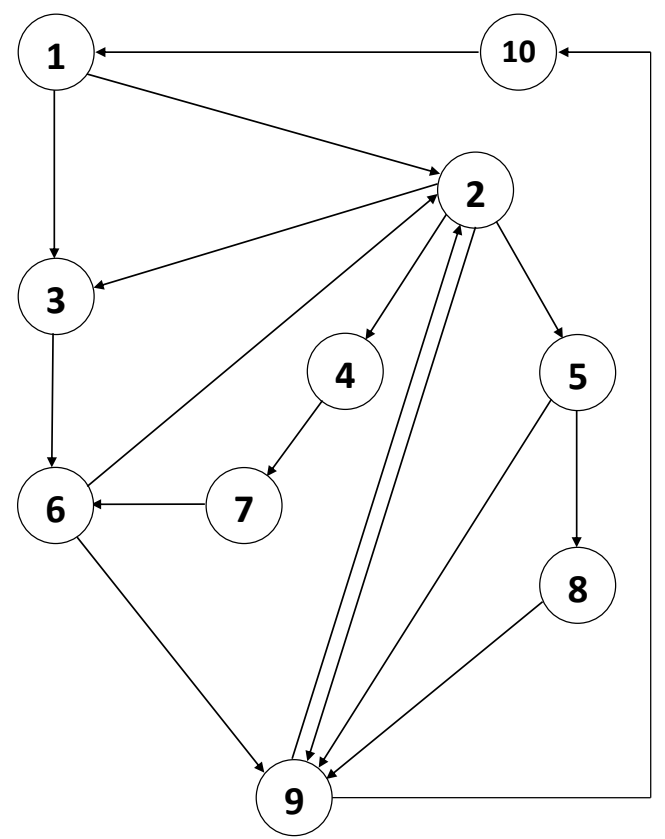

Rys. 1 Graf skierowany odwzorowania procesu eksploatacji środków transportu

$\mathbf{1}$ - postój na placu postojowym zajezdni, $\mathbf{2}$ - realizacja zadania przewozowego, 3 - interwencja jednostki pogotowia technicznego po uszkodzeniu (zdarzenie niepożadane), 4 - przestój spowodowany wypadkiem lub kolizja (zdarzenie niepożadane), 5 - diagnozowanie prewencyjne, 6 - odnowa po zajściu zdarzenia niepożąanego, 7 - akcja interwencyjno-ratownicza po wypadku lub kolizji (zdarzenie niepożądane), 8 - odnowa prewencyjna, $\mathbf{9}$ - zaopatrywanie, 10 - obstugiwanie ( $w$ dniu użytkowania, okresowe, sezonowe) 
Applying Pareto frontier to determine control strategy of technical objects... Zastosowanie frontu Pareto do wyznaczania strategii sterowania procesem...

\section{Decyzyjny model wyznaczania strategii sterowania}

Ze względu na losowy charakter czynników wpływających na przebieg procesu eksploatacji obiektów technicznych (np. środków transportu), najczęściej do matematycznego modelowania procesu eksploatacji wykorzystywane są procesy stochastyczne. Spośród procesów losowych szerokie zastosowanie w modelowaniu procesu eksploatacji obiektów technicznych znalazły procesy Markowa i semiMarkowa, natomiast $\mathrm{w}$ przypadku zagadnień dotyczących sterowania złożonymi procesami eksploatacji - decyzyjne procesy Markowa oraz semi-Markowa.

Zakładając, że analizowany model procesu eksploatacji obiektów technicznych jest procesem stochastycznym $\{X(t): t \geq 0\}$ o skończonej liczbie stanów procesu $i \in S=\{1,2, \ldots, m\}$, wówczas

$$
D_{i}=\left\{d_{i}^{(1)}\left(t_{n}\right), d_{i}^{(2)}\left(t_{n}\right), \ldots, d_{i}^{(k)}\left(t_{n}\right)\right\}
$$

oznacza zbiór wszystkich możliwych decyzji, które można zastosować w $i$-tym stanie procesu, w chwili $t_{n}$, gdzie $d_{i}^{(k)}\left(t_{n}\right)$ oznacza $k$-tą decyzję sterującą podejmowaną w $i$-tym stanie procesu, w chwili $t_{n}$.

W przypadku, gdy zadanie optymalizacyjne polega na wyborze optymalnej strategii sterowania procesem eksploatacji obiektów technicznych spośród strategii dopuszczalnych, wówczas jako strategię $\delta$ rozumie się ciąg, którego wyrazami są wektory, złożone z decyzji $d_{i}^{(k)}\left(t_{n}\right)$ podejmowanych w kolejnych chwilach $t_{n}$ zmian stanów modelowanego procesu eksploatacji obiektów technicznych

$$
\left.\delta=\left\{d_{1}^{(k)}\left(t_{n}\right), d_{2}^{(k)}\left(t_{n}\right), \ldots, d_{m}^{(k)}\left(t_{n}\right)\right]: \quad n=0,1,2, \ldots\right\} .
$$

$\mathrm{W}$ celu wyznaczenia optymalnej strategii sterowania (ciągu decyzji) możliwe jest zastosowanie decyzyjnych procesów semi-Markowa. Decyzyjny proces semimarkowski to proces stochastyczny $X(t): t \geq 0$, którego realizacja zależy od podejmowanych decyzji w chwili początkowej procesu $t_{0}$ oraz $\mathrm{w}$ chwilach zmian stanów procesu $t_{1}, t_{2}, \ldots, t_{n}, \ldots$ W przypadku stosowania decyzyjnych procesów semi-Markowa, podjęcie $\mathrm{w}$ chwili $t_{n}, k$-tej decyzji sterującej $\mathrm{w} i$-tym stanie procesu, oznacza wybór $i$-tego wiersza jądra procesu, ze zbioru

$$
\left\{Q_{i j}^{(k)}(t): t \geq 0, \quad d_{i}^{(k)}\left(t_{n}\right) \in D_{i}, \quad i, j \in S\right\},
$$

gdzie

$$
Q_{i j}^{(k)}(t)=p_{i j}^{(k)} \cdot F_{i j}^{(k)}(t) .
$$

Wybór $i$-tego wiersza jądra procesu wyznacza probabilistyczny mechanizm ewolucji procesu w przedziale czasu $\left.<t_{n} ; t_{n+1}\right)$. 
Oznacza to, że dla procesu semi-markowskiego, w przypadku zmiany stanu procesu $\mathrm{z}$ dowolnego na $i$-ty (wejścia do $i$-tego stanu procesu) w chwili $t_{n}$, podejmowana jest decyzja $d_{i}^{(k)}\left(t_{n}\right) \in D_{i}$ oraz zgodnie z rozkładem $\left(p_{i j}^{(k)}: j \in S\right)$ zostaje wygenerowany $j$-ty stan procesu, do którego następuje przejście $\mathrm{w}$ chwili $t_{n+1}$. Jednocześnie zgodnie z rozkładem określonym przez dystrybuantę $F_{i j}^{(k)}(t)$, zostaje wygenerowana długość przedziału czasu $<t_{n} ; t_{n+1}$ ) pozostawania w $i$-tym stanie procesu, gdy następnym stanem jest stan $j$-ty.

Wybór właściwej strategii sterowania $\delta$ nazywanej strategią optymalną $\delta^{*}$, dotyczy sytuacji, gdy funkcja (funkcje) stanowiąca kryterium wyboru strategii optymalnej przyjmuje wartość ekstremalną (minimalną lub maksymalną)

$$
f_{C}\left(\delta^{*}\right)=\min _{\delta}\left[f_{C}(\delta)\right] \operatorname{lub} f_{C}\left(\delta^{*}\right)=\max _{\delta}\left[f_{C}(\delta)\right] .
$$

W pracy funkcje kryterialne stanowią gotowość pojedynczego obiektu technicznego $G^{O T}(\delta)$ oraz jednostkowe ryzyko zdarzenia niepożądanego $r^{O T}(\delta)$ [PLN/h]:

$$
\begin{gathered}
f_{C_{1}}(\delta)=G^{O T}(\delta)=\sum_{i \in S_{G}} p_{i}^{*}(\delta)=\frac{\sum_{i \in S_{G}} \pi_{i} \cdot \Theta_{i}(\delta)}{\sum_{i \in S} \pi_{i} \cdot \Theta_{i}(\delta)}, \\
f_{C_{2}}(\delta)=r^{O T}(\delta)=\sum_{i \in S_{N}} c_{i}(\delta) \cdot p_{i}^{*}(\delta)=\frac{\sum_{i \in S_{N}} c_{i}(\delta) \cdot \pi_{i} \cdot \Theta_{i}(\delta)}{\sum_{i} \pi_{i} \cdot \Theta_{i}(\delta)},
\end{gathered}
$$

gdzie:

$S_{G} \subset S$-zbiór stanów gotowości modelowanego procesu eksploatacji,

$S_{N} \subset S$ - zbiór stanów niepożądanych modelowanego procesu eksploatacji,

$c_{i}(\delta) \quad$ - dochody jednostkowe generowane w stanach procesu $X(t)$,

$p_{i}^{*}(\delta)$ - prawdopodobieństwa graniczne przebywania w stanach rozpatrywanego procesu $X(t)$, wyznaczone na podstawie twierdzenia granicznego dla procesów semimarkowskich [3]

$$
p_{i}^{*}(\delta)=\frac{\pi_{i} \cdot \Theta_{i}(\delta)}{\sum_{i \in S} \pi_{i} \cdot \Theta_{i}(\delta)},
$$

gdzie:

$\Theta_{i}(\delta)$ - wartości średnie bezwarunkowych czasów trwania stanów procesu, $\pi_{i}$ - prawdopodobieństwa rozkładu stacjonarnego włożonego łańcucha Markowa, który spełnia układ równań liniowych

$$
\sum_{i \in S} \pi_{i} \cdot p_{i j}=\pi_{j}, \quad j \in S, \quad \sum_{i \in S} \pi_{i}=1,
$$


Applying Pareto frontier to determine control strategy of technical objects... Zastosowanie frontu Pareto do wyznaczania strategii sterowania procesem...

$p_{i j}$ - prawdopodobieństwa warunkowe przejścia ze stanu $i$ do stanu $j$, według zależności:

$$
\begin{gathered}
p_{i j}=\lim _{t \rightarrow \infty} p_{i j}(t), \\
p_{i j}(t)=P\{X(t)=j \mid X(0)=i\} .
\end{gathered}
$$

Wówczas wybór strategii optymalnej $\delta^{*}$ dokonywany jest na podstawie następujących kryteriów:

$$
\begin{aligned}
& G^{O T}\left(\delta^{*}\right)=\max _{\delta}\left[G^{O T}(\delta)\right], \\
& r^{O T}\left(\delta^{*}\right)=\min _{\delta}\left[r^{O T}(\delta)\right] .
\end{aligned}
$$

Dogodne narzędzie wyboru strategii $\delta^{*}$ sterowania procesem eksploatacji obiektów technicznych, na podstawie opracowanego semi-markowskiego modelu tego procesu, stanowi algorytm symulowanego wyżarzania. W przypadku zastosowania algorytmu symulowanego wyżarzania do wyznaczania strategii optymalnej $\delta^{*}$ sterowania procesem eksploatacji obiektów technicznych, należy przyjąć następujące założenia:

- badany model procesu eksploatacji obiektów technicznych jest $m$ stanowym procesem stochastycznym,

- w każdym stanie modelu procesu eksploatacji można zastosować jedną z dwóch możliwych decyzji $D=\{0,1\}$,

- jeśli decyzje zostaną oznaczone jako 0 i 1, to liczba możliwych do zastosowania strategii sterowania, dla $m$ stanowego modelu procesu eksploatacji obiektów technicznych, wynosi $2^{m}$,

- zbiór strategii sterowania jest zbiorem funkcji $\delta: S \rightarrow D$.

$\mathrm{Na}$ podstawie powyższych założeń, każdą możliwą strategię sterowania można przedstawić jako $m$ pozycyjny ciąg złożony z 0 i 1 , wówczas przykładowa strategia sterowania dla $m=10$-stanowego modelu procesu eksploatacji, jest określona następująco: $\delta=[1,1,0,1,1,0,1,0,0,1]$. Następnie dla 10-stanowego semi-markowskiego modelu procesu eksploatacji środków transportu przedstawionego na rysunku 1 oraz danych uzyskanych z badań rzeczywistego systemu eksploatacji, wykonano obliczenia za pomocą opracowanego programu komputerowego z zastosowaniem wielokryterialnego algorytmu symulowanego wyżarzania.

\section{Wyznaczenie racjonalnej strategii sterowania}

Przedstawiony przykład został opracowany na podstawie danych eksploatacyjnych uzyskanych z badań rzeczywistego systemu eksploatacji środków transportu (autobusów komunikacji miejskiej). W badanym systemie transportowym użytkowane są 182 autobusy miejskie, a procesy obsługowo-naprawcze realizowane są na stanowiskach zaplecza technicznego oraz przez jednostki pogotowia technicznego. 
Sterowanie procesem eksploatacji możliwe jest w wyniku podejmowania odpowiednich decyzji w stanach decyzyjnych procesu (tabela 1). Dla rozpatrywanego modelu procesu eksploatacji środków transportu na podstawie danych eksploatacyjnych oszacowano wartości elementów macierzy prawdopodobieństw przejść $P$, określono możliwe decyzje podejmowane w decyzyjnych stanach procesu (tabela 1) oraz wyznaczono bezwarunkowe czasy $\mathrm{i}$ jednostkowe dochody generowane w stanach procesu $X(t)$ (tabela 2).

W prezentowanym modelu wyróżniono następujące stany gotowości: 1 - postój na placu zajezdni, 2 - realizacja zadania przewozowego; oraz następujące stany niepożądane procesu: $\mathbf{3}$ - interwencja jednostki pogotowia technicznego po uszkodzeniu, 4 - przestój spowodowany wypadkiem lub kolizją, 6 - odnowa po zajściu zdarzenia niepożądanego, 7 - akcja interwencyjno-ratownicza po wypadku lub kolizji.

$$
P=\left|\begin{array}{cccccccccc}
0 & 0,9609 & 0,0391 & 0 & 0 & 0 & 0 & 0 & 0 & 0 \\
0 & 0 & 0,2321 & 0,0030 & 0,4988 & 0 & 0 & 0 & 0,2661 & 0 \\
0 & 0 & 0 & 0 & 0 & 1 & 0 & 0 & 0 & 0 \\
0 & 0 & 0 & 0 & 0 & 0 & 1 & 0 & 0 & 0 \\
0 & 0 & 0 & 0 & 0 & 0 & 0 & 0,0799 & 0,9201 & 0 \\
0 & 0,4702 & 0 & 0 & 0 & 0 & 0 & 0 & 0,5298 & 0 \\
0 & 0 & 0 & 0 & 0 & 1 & 0 & 0 & 0 & 0 \\
0 & 0 & 0 & 0 & 0 & 0 & 0 & 0 & 1 & 0 \\
0 & 0,2242 & 0 & 0 & 0 & 0 & 0 & 0 & 0 & 0,7758 \\
1 & 0 & 0 & 0 & 0 & 0 & 0 & 0 & 0 & 0
\end{array}\right|
$$

Tab. 1 Decyzje w stanach analizowanego procesu

\begin{tabular}{|c|c|c|}
\hline $\begin{array}{c}\text { Stan } \\
\text { procesu }\end{array}$ & Decyzja, $0 "-d_{i}^{(0)}$ & Decyzja, $1 "-d_{i}^{(1)}$ \\
\hline 2 & $\begin{array}{l}\text { Trasa oznaczona kodem L } \\
\text { („lekkie” warunki realizacji } \\
\text { zadania przewozowego) }\end{array}$ & $\begin{array}{l}\text { Trasa oznaczona kodem T } \\
\text { (,trudne” warunki realizacji } \\
\text { zadania przewozowego) }\end{array}$ \\
\hline 3 & $\begin{array}{c}\text { Interwencja jednostki PT typu P } \\
\text { (zakres podstawowy) }\end{array}$ & $\begin{array}{c}\text { Interwencja jednostki PT typu R } \\
\text { (zakres rozszerzony) }\end{array}$ \\
\hline 5 & $\begin{array}{l}\text { Diagnozowanie prewencyjne } \\
\text { typu P (zakres podstawowy) }\end{array}$ & $\begin{array}{l}\text { Diagnozowanie prewencyjne } \\
\text { typu R (zakres rozszerzony) }\end{array}$ \\
\hline 6 & $\begin{array}{c}\text { Odnowa po zajściu zdarzenia } \\
\text { niepożądanego typu P } \\
\text { (zakres podstawowy) }\end{array}$ & $\begin{array}{c}\text { Odnowa po zajściu zdarzenia } \\
\text { niepożądanego typu R } \\
\text { (zakres rozszerzony) }\end{array}$ \\
\hline 7 & $\begin{array}{c}\text { Akcja interwencyjno-ratownicza } \\
\text { typu N (normalna) }\end{array}$ & $\begin{array}{c}\text { Akcja interwencyjno-ratownicza } \\
\text { typu I (intensywna) }\end{array}$ \\
\hline 8 & $\begin{array}{c}\text { Odnowa prewencyjna typu P } \\
\text { (zakres podstawowy) }\end{array}$ & $\begin{array}{c}\text { Odnowa prewencyjna typu } \mathrm{R} \\
\text { (zakres rozszerzony) }\end{array}$ \\
\hline 9 & Obsługiwanie typu N (normalne) & $\begin{array}{c}\text { Obsługiwanie typu I } \\
\text { (intensywne) }\end{array}$ \\
\hline
\end{tabular}


Applying Pareto frontier to determine control strategy of technical objects... Zastosowanie frontu Pareto do wyznaczania strategii sterowania procesem...

Tab. 2 Średnie bezwarunkowe czasy $\bar{\Theta}_{i}$ oraz dochody jednostkowe $c_{i}$ generowane $w$ zależności od zastosowanej decyzji $w$ stanach procesu $X(t)$

\begin{tabular}{|c|c|c|c|c|}
\hline $\begin{array}{c}\text { Stan } \\
\text { procesu }\end{array}$ & $\bar{\Theta}_{i}^{(0)}[\mathrm{h}]$ & $\bar{\Theta}_{i}^{(1)}[\mathrm{h}]$ & $c_{i}^{(0)}[\mathrm{PLN} / \mathrm{h}]$ & $c_{i}^{(1)}[\mathrm{PLN} / \mathrm{h}]$ \\
\hline $\mathbf{1}$ & 5,659 & 5,659 & $-6,77$ & $-6,77$ \\
\hline $\mathbf{2}$ & 8,852 & 7,967 & 28,44 & 33,56 \\
\hline $\mathbf{3}$ & 0,586 & 0,714 & $-127,09$ & $-79,08$ \\
\hline $\mathbf{4}$ & 0,373 & 0,373 & $-242,80$ & $-242,80$ \\
\hline $\mathbf{5}$ & 0,814 & 0,577 & $-54,98$ & $-83,79$ \\
\hline $\mathbf{6}$ & 2,888 & 2,303 & $-98,97$ & $-121,70$ \\
\hline $\mathbf{7}$ & 2,212 & 1,739 & $-403,63$ & $-538,18$ \\
\hline $\mathbf{8}$ & 2,940 & 2,150 & $-86,89$ & $-112,98$ \\
\hline $\mathbf{9}$ & 0,452 & 0,452 & $-23,09$ & $-23,09$ \\
\hline $\mathbf{1 0}$ & 0,682 & 0,454 & $-164,72$ & $-204,72$ \\
\hline
\end{tabular}

Następnie wykonano obliczenia za pomocą opracowanego programu komputerowego, $\mathrm{z}$ zastosowaniem algorytmu symulowanego wyżarzania, napisanego w: $R$ Development Core Team (2017). R: A language and environment for statistical computing. $R$ Foundation for Statistical Computing, Vienna, Austria. ISBN 3-900051-07-0. Na podstawie wykonanych obliczeń, dla przyjętych kryteriów wyznaczono optymalne (quasi-optymalne) strategie sterowania procesem eksploatacji realizowanym w badanym systemie transportowym. Wyniki obliczeń przedstawiono na rysunkach 2 i 3 oraz w tabeli 3 .

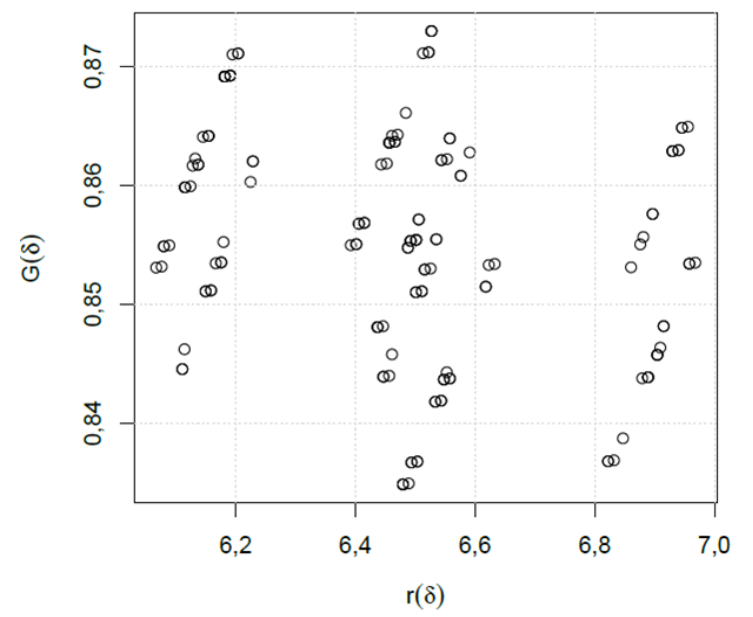

Rys. 2 Wyniki otrzymane $w$ kolejnych iteracjach za pomoca algorytmu symulowanego wyżarzania 
Klaudiusz Migawa, Leszek Knopik, Andrzej Neubauer, Agnieszka Sottysiak

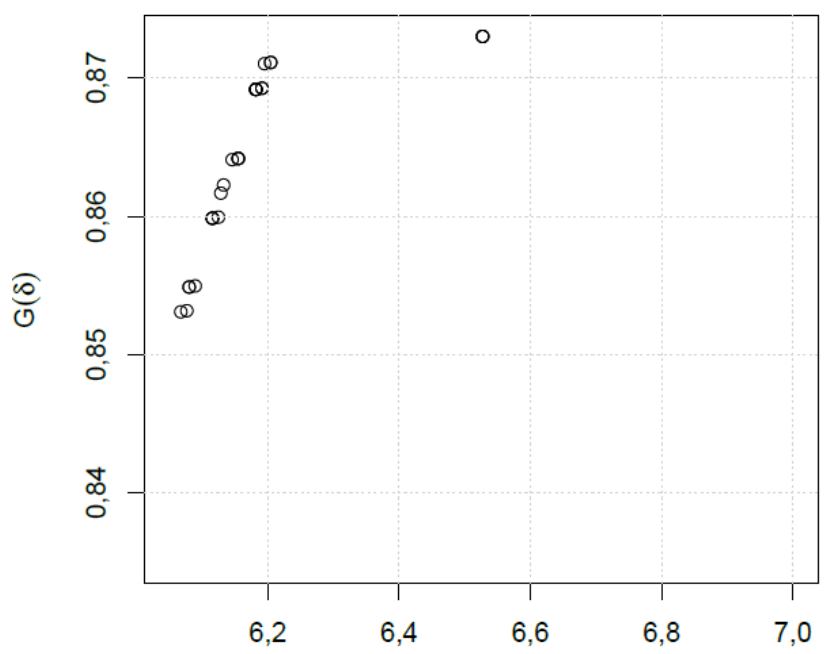

$\mathrm{r}(\delta)$

Rys. 3 Front Pareto rozwiazań optymalnych wyznaczony za pomoca algorytmu symulowanego wyżarzania

Tab. 3 Optymalne strategie sterowania $\delta^{*}$ oraz wartości funkcji kryterialnych wyznaczone za pomoca algorytmu symulowanego wyżarzania

\begin{tabular}{|c|c|c|}
\hline Strategia $\delta^{*}$ & $G\left(\delta^{*}\right)$ & $r\left(\delta^{*}\right)[\mathrm{PLN} / \mathrm{h}]$ \\
\hline$[0,0,1,1,0,1,0,0,0,0]$ & 0,8531 & 6,0673 \\
\hline$[1,0,1,0,0,1,1,0,1,0]$ & 0,8532 & 6,0764 \\
\hline$[1,0,1,1,0,1,0,1,1,0]$ & 0,8549 & 6,0800 \\
\hline$[0,0,1,1,0,1,1,1,1,0]$ & 0,8550 & 6,0892 \\
\hline$[1,0,1,1,1,1,0,0,1,0]$ & 0,8599 & 6,1154 \\
\hline$[1,0,1,0,1,1,1,0,1,0]$ & 0,8599 & 6,1246 \\
\hline$[0,0,1,0,1,1,0,1,1,0]$ & 0,8617 & 6,1283 \\
\hline$[0,0,1,1,0,1,0,0,1,1]$ & 0,8623 & 6,1325 \\
\hline$[0,0,1,1,0,1,0,1,0,1]$ & 0,8641 & 6,1455 \\
\hline$[0,0,1,0,0,1,1,1,1,1]$ & 0,8642 & 6,1548 \\
\hline$[0,0,1,0,1,1,0,0,0,1]$ & 0,8692 & 6,1817 \\
\hline$[0,0,1,1,1,1,1,0,1,1]$ & 0,8693 & 6,1910 \\
\hline$[0,0,1,0,1,1,0,1,1,1]$ & 0,8710 & 6,1949 \\
\hline$[0,0,1,1,1,1,1,1,0,1]$ & 0,8711 & 6,2043 \\
\hline
\end{tabular}


Applying Pareto frontier to determine control strategy of technical objects... Zastosowanie frontu Pareto do wyznaczania strategii sterowania procesem...

\section{Podsumowanie}

Na podstawie wyników badań eksploatacyjnych, zrealizowanych w rzeczywistym systemie eksploatacji środków transportu, wyznaczono dane wejściowe opracowanego algorytmu symulowanego wyżarzania oraz wykonano obliczenia. W efekcie wyznaczono wartości funkcji kryterialnych oraz odpowiadający im zbiór strategii sterowania będący zbiorem rozwiązań optymalnych w sensie Pareto. Następnie na podstawie otrzymanych wyników można dokonać wyboru jednego rozwiązania spośród wyznaczonego zbioru rozwiązań optymalnych leżących na tzw. froncie Pareto.

Wybór taki dokonywany jest zazwyczaj przez decydenta (zespół decydentów) systemu, na podstawie dodatkowych przesłanek dotyczących zarówno konkretnej sytuacji decyzyjnej oraz aktualnych warunków w jakich funkcjonuje system eksploatacji.

\section{Literatura}

[1] Czyżak P., Jaszkiewicz A.: Pareto simulated annealing - A metaheuristic technique for multiple-objective combinatorial optimization. J. Multi-Criteria Decision Anal., vol. 7, 1998, 34-47.

[2] Grabski F.: Analiza ryzyka w decyzyjnych semi-markowskich modelach procesu eksploatacji. XXXVIII Zimowa Szkoła Niezawodności, Szczyrk, 2010, 43-52.

[3] Grabski F.: Semi-Markov processes: Applications in system reliability and maintenance. Elsevier, Amsterdam, 2014.

[4] Hapke M., Jaszkiewicz A., Słowiński R.: Pareto simulated annealing for fuzzy multi-objective combinatorial optimization. J. Heuristics, vol. 6, no. 3, 2000, 329-345.

[5] Knopik L., Migawa K., Wdzięczny A.: Profit optimalization in operation systems. Polish Maritime Research, vol. 23, no. 1(89), 2016, 93-98.

[6] Kulkarni V. G.: Modeling and analysis of stochastic systems. Chapman \& Hall, New York, 1995.

[7] Lee K. W.: Stochastic models for random-request availability. IEEE Trans. Reliability 49, 2000, 80-84.

[8] Migawa K., Knopik L., Sołtysiak A., Kolber P.: The method of risk assessment in transport system. Engineering Mechanics, Institute of Thermomechanics Academy of Sciences of the Czech Republic, 2017, 658-661.

[9] Migawa K., Knopik L., Wawrzyniak S.: Application of genetic algorithm to control the availability of technical systems. Engineering Mechanics, Institute of Thermomechanics Academy of Sciences of the Czech Republic, 2016, 386-389.

[10] Nam D. K., Park C.: Multiobjective simulated annealing: A comparative study to evolutionary algorithms," Int. J. Fuzzy Syst., vol. 2, no. 2, 2000, 87-97.

[11] Suman B., Kumar P.: A survey of simulated annealing as a tool for single and multiobjective optimization. Journal of the Operational Research Society, vol. 57, 2006, 1143-1160.

[12] Suppapitnarm A., Seffen K. A., Parks G. T., Clarkson P.: A simulated annealing algorithm for multiobjective optimization," Eng. Opt., vol. 33, 2000, 59-85. 
[13] Szubartowski M., Migawa K., Neubauer A., Knopik L.: Method of determining optimal control strategy. $58^{\text {th }}$ International Conference of Machine Design Departments - ICMD 2017, Prague, Czech Republic, 2017, 380-385.

[14] Ulungu E. L., Teghaem J., Fortemps P., Tuyttens D.: MOSA method: A tool for solving multiobjective combinatorial decision problems," J. Multi-Criteri Decision Anal., vol. 8, 1999, 221-236.

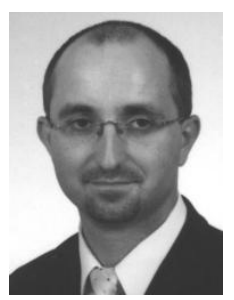

Dr hab. inz. Klaudiusz Migawa, prof. nadzw. UTP, pracownik Wydziału Inżynierii Mechanicznej Uniwersytetu TechnologicznoPrzyrodniczego $w$ Bydgoszczy. W pracy naukowej zajmuje sie problematyka oceny $i$ sterowania poziomem efektywności, niezawodności, gotowości oraz bezpieczeństwa złożonych systemów eksploatacji obiektów technicznych. Autor prac naukowych $z$ zakresu modelowania systemów $i$ procesów eksploatacji środków transportu (Udziat 25\%).

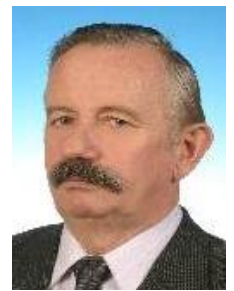

Dr hab. Leszek Knopik, prof. nadzw. UTP, pracownik Wydziatu Zrzadzania Uniwersytetu Technologiczno-Przyrodniczego $w$ Bydgoszczy. W pracy naukowej zajmuje się problematyka budowania modeli matematycznych złożonych procesów eksploatacji, zadaniami teorii i praktyki niezawodności. Autor prac naukowych $z$ zakresu modelowania systemów $i$ procesów eksploatacji obiektów technicznych z zastosowaniem metod badań operacyjnych, rachunku prawdopodobieństwa i procesów Markowa oraz semiMarkowa (Udziat 25\%).

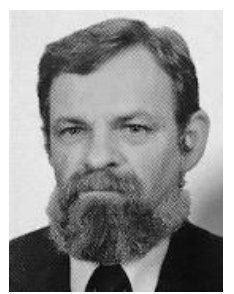

Dr Andrzej Neubauer, pracownik Wydziatu Nauk Ekonomicznych $i$ Zarzadzania Uniwersytetu Mikotaja Kopernika w Toruniu. $W$ pracy naukowej zajmuje sie problemami dotyczacymi modelowania $i$ symulacji procesów eksploatacji, sterowania procesami $w$ oparciu o procesy Markowa $i$ semi-Markowa. Interesuje się też zastosowaniem algorytmów genetycznych, ewolucyjnych $i$ symulowanego wyzarzania do symulacyjnej optymalizacji procesów sterowania (Udział 25\%).

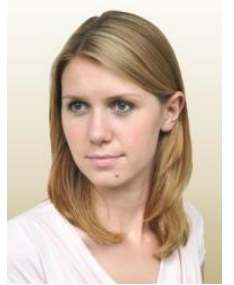

Mgr in:. Agnieszka Soltysiak, pracownik Wydziału Inżynierii Mechanicznej Uniwersytetu Technologiczno-Przyrodniczego w Bydgoszczy. Studentka studiów doktoranckich na Wydziale Inżynierii Mechanicznej UTP w Bydgoszczy w dyscyplinie Budowa $i$ Eksploatacja Maszyn. $W$ pracy naukowej zajmuje sie problematyka modelowania procesów eksploatacji obiektów technicznych oraz sterowania poziomem bezpieczeństwa złożonych systemów technicznych (Udziat 25\%). 